\title{
Assessment of pharmacotherapeutic safety of medical prescriptions for elderly residents in a long-term care facility
}

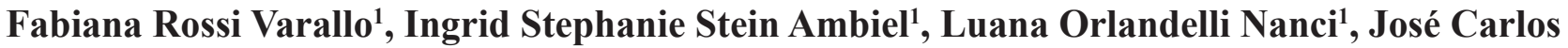 \\ Fernandes Galduróz ${ }^{2}$, Patricia de Carvalho Mastroianni ${ }^{1, *}$
}

${ }^{1}$ School of Pharmaceutical Sciences, State University of São Paulo “Júlio de Mesquita Filho”, ${ }^{2}$ School of Medicine, Federal University of São Paulo

\begin{abstract}
The present study aimed to estimate the prevalence of elderly using potentially inappropriate medications (PIM) and with occurrence of potentially hazardous drug interactions (PHDI); to identify the risk factors for the prescription of PIM and to evaluate the impact of pharmaceutical intervention (PI) for the prescription of safer therapeutic alternatives. Therefore, a cross-sectional study was performed in a long-term care facility in São Paulo State, between December/2010 and January/2011. The medical records of the patients $\geq 60$ years old who took any drugs were consulted to assess the pharmacotherapeutic safety of the medical prescriptions, in order to identify PIM and PHDI, according to the Beers (2003) and World Health Organization criteria, respectively. PI consisted of a guidance letter to the physician responsible for the institution, with the suggestions of safer equivalent therapeutics. Approximately $88 \%$ of the elderly took at least one drug, and for $30 \%$ of them the PIM had been prescribed. Most of the PIM identified (53.4\%) act on the central nervous system. Among the 13 different DI detected, 6 are considered PHDI. Polypharmacy was detected as a risk factor for PIM prescription. After the PI there was no change in medical prescriptions of patients who had been prescribed PIM or PHDI. The data suggests that PI performed by letter, as the only interventional, method was ineffective. To contribute it a wide dissemination of PIM and PHDI among prescriber professionals is necessary for the selection of safer treatment for elderly. Additionally, a pharmacist should be part of the health care team in order to help promote rational use of medicines.
\end{abstract}

Uniterms: Drugs/interactions. Elderly people/inappropriated use of medicines. Long-term care facility. Medication/errors. Safety management.

O presente estudo teve como objetivos estimar a prevalência de idosos em uso de medicamentos potencialmente impróprios (MPI) e com ocorrência de interações medicamentosas potencialmente perigosas (IMPP); identificar os fatores de risco para a prescrição de MPI e avaliar o impacto de intervenção farmacêutica (IF) para a prescrição de alternativas terapêuticas mais seguras. Para tanto, realizou-se estudo transversal em instituição de longa permanência do interior de São Paulo, de dezembro/2010 a janeiro/ 2011. Os prontuários médicos dos pacientes $\geq 60$ anos e que utilizavam pelo menos um medicamento foram consultados para avaliar a segurança farmacoterapêutica das prescrições médicas, identificando-se os MPI e as IMPP, segundo critérios de Beers (2003) e o critério da Organização Mundial da Saúde, respectivamente. A IF constou de carta de orientação ao médico da instituição, com sugestão de equivalentes terapêuticos mais seguros. Aproximadamente $88 \%$ dos idosos haviam utilizado pelo menos um medicamento e, para 30\% deles, havia pelo menos um MPI prescrito. A maioria dos MPI identificados $(53,4 \%)$ age no sistema nervoso central. Entre as 13 interações medicamentosas detectadas, 6 são consideradas IMPP. A polimedicação foi detectada como fator de risco para a prescrição de MPI. Após a IF, não houve alterações nas prescrições médicas dos pacientes que apresentavam MPI e IMPP prescritos. Os dados sugerem que IF realizadas por cartas, como único método interventivo, não são efetivas. Para contribuir com a seleção de farmacoterapia mais segura para idosos é necessária ampla

*Correspondence: P. C. Mastroianni. Faculdade de Ciências Farmacêuticas UNESP. Rodovia Araraquara - Jaú, km 1 - 14801-902 - Araraquara - SP, Brasil. E-mail: patriciamastroianni@yahoo.com.br 
divulgação dos MPI e IMPP entre os profissionais prescritores. Além disso, o farmacêutico deve fazer parte das equipes de saúde para auxiliar na promoção do uso racional de medicamentos.

Unitermos: Medicamentos/interação. Idosos/uso impróprio de medicamentos. Assistência de longa duração. Medicação/erros. Gerenciamento de segurança.

\section{INTRODUCTION}

Brazil is in a demographic transition process, in which a marked population aging is observed. It is estimated that in 2020 the country will be the sixth in the world as regards population of elderly people (Carvalho, Garcia, 2003). As a result, an epidemiologic transition is also observed, with changes in the morbidity and mortality profiles (IBGE, 2009), since the country has passed from the typical profile of a young population to one characteristic of seniors, with more complex diseases and expensive treatments (Gordilho et al., 2000) Thus, due to clinical conditions of geriatric patients, the use of polypharmacy to treat their pathologies is frequent, which favors the occurrence of medication errors, such as the prescription of potentially inappropriate medication (PIM) and potentially hazardous drug interactions (PHDI).

Medications are considered inappropriate when the risk of their use overcomes the benefit (Beers et al., 1991), once they are drugs with high risk of leading to adverse drug reactions (ADR), without sufficient evidence of benefits, and when safer pharmacotherapeutic alternatives are available (Gallagher et al., 2008a; Fick et al., 2003). Furthermore, the exposure to PIM may increase the utilization of health care services (Fick et al., 2008) and medical costs (Akazawa et al., 2010).

The aging process induces physiological alterations in the body, such as reduction in rates of hepatic clearance, glomerular filtration, muscle mass and homeostasis mechanisms (Corsonello et al., 2010). These changes can influence pharmacokinetic and pharmacodynamic parameters. Therefore, it is necessary to elaborate criteria to provide safe and rational therapeutic schemes for seniors (Klotz et al., 2008). However, the prescription of PIM is common among older people (Laroche et al., 2007) and, in spite of the recognized gravity of the problem, there is no consensus about the best form of prevention (O'Mahony, Gallagher, 2008).

Castelino et al. (2009) state that promising results are expected with pharmaceutical intervention (PI) regarding the safety assessment of prescriptions for elderly people. In these analyses, tools that combine explicit (Bongue et al., 2009) and implicit indicators of prescriptions can be used to see PIM, being the Beers criteria (Fick et al.,
2003) the most commonly adopted, since it is the most disseminated method in the literature (O'Mahony, Gallagher, 2008). However, the application of these instruments must not substitute clinical and pharmacological analyses for the selection of drugs for patients.

In this context, since the proportion of PIM takers is an important indicator of medical-sanitary assistance, useful to evaluate nursing homes (Rozenfeld, 2003), and considering that pharmacoepidemiological studies rarely include elderly living in these institutions (Morais, 1998), the present study was aimed to: estimate the prevalence of institutionalized elderly people using PIM; identify the PIM taken and the potentially hazardous drug interactions (PHDI); propose a pharmaceutical intervention for physicians, and evaluate its impact on the prescription of safer therapeutic alternatives for the elderly.

\section{METHODS}

A cross-sectional study was performed in a public long-term care facility located in the state of São Paulo, Brazil, from December 2010 to January 2011. All data was obtained from the medical records of the elderly people residing in the institution. Those who were $\geq 60$ years old and had taken at least one drug were considered eligible for the study. The medical records which were illegible or lacked information regarding drugs were excluded.

A validated form was used for data collection. This instrument included the identification of the patient (initials of the name and date of birth), demographic characteristics [gender and age group (I: 60 to 69 years; II: 70 to 79 years; III: $\geq 80$ years)] and the drugs taken four weeks prior to data collection. Beers criteria (Fick et al., 2003) were used to identify PIM, since it is the instrument most widely used in literature (O’Mahony, Gallagher, 2008), and also lists the drugs that should be avoided, independently of the diagnosis or clinical condition of the patient.

PIM identified were classified regarding therapeutic classes, according to the Anatomical Therapeutic Chemical Code (ATC code); if they belonged or not to the national list of essential medicines (RENAME 2010) (based on the effectiveness, safety, quality and cost criteria), and according to the severity of the outcomes related to the use of these drugs (Fick et al., 2003). The drug interactions 
(DI) were detected through MICROMEDEX® database (accessed through the DRUGREAX in www.portaldapesquisa.com.br address) and the labels of the drugs approved by the National Agency of Sanitary Vigilance (ANVISA). DI related to PIM were classified according to the severity (major, moderate and minor) and their potential hazard (WHO, 2004).

Only one Pharmaceutical intervention (PI) was made which comprised the elaboration of a guideline letter to the physician responsible for the long-term care facility. This document contained the identification of the elderly who had taken PIM, the PIM utilized and the DI observed, as well as the suggestions of safer pharmacotherapy for this age group, which was selected based on the scientific literature (pharmacology books and papers published in PUBMED database). After PI, medical records of patients who had taken PIM and experienced DI were consulted to compare the prevalence of PIM prescription before and after intervention, and to assess the impact of this methodology.

Identified PIM and observed DI were presented in absolute and relative frequencies. Odds ratio (OR) of gender was calculated to identify risk factor for the use of PIM. Chi-square and Mann-Whitney tests were applied in order to assess association among age groups and use of PIM, as well as statistical differences between patients who use polypharmacy from those who do not, respectively. The level of significance was set at $5 \%$.

The study protocol was approved by the Ethics Committee in Research of UNIFESP.

\section{RESULTS}

During the period of the study, 141 subjects lived in the long-term care institution, being that 21 of them did not meet the inclusion criteria (five were aged $<60$ years and 16 did not take any drugs) and $120(88.2 \%)$ were considered eligible for the research.

The estimated prevalence of elderly using PIM was $29.2 \%(35 / 120)$. Most of them were women [65.7\% $(23 / 35)]$, although gender was not detected as risk factor for use of PIM [OR=1.27; IC=95\% (0.6-2.9); $\mathrm{p}=0.56]$.

Regarding age groups, 21 elderly belonged to group I, 40 to group II and 59 to group III, of whom 10, 11 and 14 patients, respectively, had taken PIM. However, there was no association among the prescription of PIM and age group ( $\mathrm{p}=0.11)$. Therefore, there is no evidence that the older elderly (group III) are more affected by the prescription of inappropriate drugs.

According to Mann-Whitney statistical test, PIM takers administered more drugs $(\mathrm{p}<0.0001)$ than patients without use of PIM, indicating that polypharmacy increases the odds of PIM prescription among elderly people.

Out of the 116 different drugs prescribed for the elderly, 14 (12.1\%) are considered PIM (Table I), out of which seven (50.0\%) (amiodarone, amitriptyline, diazepam, digoxin, fluoxetine, methyldopa and nitrofurantoin) are essential drugs, according to RENAME 2010 and $16^{\text {th }}$ Model List of Essential Medicines of World Health Organization (2010). Most PIM utilized act on the central nervous system (53.4\%), followed by $33.3 \%$ which act on the cardiovascular system (Table I). For $64.3 \%$ (9/14) of the PIM identified, the use was classified as highly severe hazardous (Fick et al., 2003) (Table I). Thirteen DI involving PIM were observed in 22 prescriptions; six of them (46.1\%) being potentially hazardous according to the $\mathrm{WHO}(\mathrm{WHO}, 2004)$ and $15.4 \%$ $(2 / 13)$ have major severity (Table II).

In the phase of pharmaceutical intervention, safer therapeutic equivalents were suggested for the elderly regarding the 14 PIM identified (Table III).

However, after the guidance letter (PI) was handed in to the physician responsible for the institution, there was no change in drug prescriptions of the inpatients who were taking PIM. Therefore, none of the safer therapeutic equivalents suggested were prescribed as a substitute of PIM identified.

\section{DISCUSSION}

The Beer's List (Fick et al., 2003) is the most applied criteria in the literature for assessing the quality of medical prescription for the elderly. It comprises two lists of medicines, being that the first comprehends 48 drugs or classes of drugs which should be avoided, independently of clinical conditions of the elderly patient; and the second one comprises the drugs that should be avoided considering 20 pathologies or health conditions of the patient.

According to this list, the prevalence of elderly using PIM in the present study was approximately $30 \%$. Other researches show that the prevalence of institutionalized older people who take at least one PIM ranges from $27.6 \%$ to $46.2 \%$ (Ruggiero et al., 2010; Castellar et al., 2007; Azoulay et al., 2005). The prescription of PIM must follow judicious protocols, since their administration may double the odds of hospitalization of elderly people (Albert et al., 2010), as well as the demand for health services (Fick et al, 2008). It can also generate hospital expenses (Akazawa et al., 2010). Thus, it is necessary that health institutions promote continuing education for their professionals, in order to allow them to carry-out quality medical assistance, considering the elderly needs. Most of identified PIM (53.4\%) act on the central nervous system, 
TABLE I - Frequency of the potentially inappropriate medication identified according to Beers criteria (Fick et al., 2003), classified according to the ATC, the severity of its use and the justification for being considered inappropriate for the elderly. Araraquara, SP, Brazil $(n=14)$

\begin{tabular}{|c|c|c|c|c|}
\hline ATC code & Drug & $\mathrm{N}$ & Severity & Justification for inappropriate use \\
\hline \multirow{4}{*}{ Nervous System } & diazepam & $13(28,9)$ & High & $\begin{array}{l}\text { Long half-life in elderly patients; causes prolonged sedation, } \\
\text { increasing risks of falls and fractures. }\end{array}$ \\
\hline & amitriptyline & $4(8,9)$ & High & Causes severe anticholinergic effects. \\
\hline & thioridazine & $4(8,9)$ & High & $\begin{array}{l}\text { Great potential for causing extra-pyramidal adverse effects and } \\
\text { adverse effects in the central nervous system. }\end{array}$ \\
\hline & fluoxetine & $3(6,7)$ & High & $\begin{array}{l}\text { Long half-life and risk of producing excessive stimulation in the } \\
\text { central nervous system, sleep problems and increase in agitation; } \\
\text { safer alternatives are available. }\end{array}$ \\
\hline \multirow{7}{*}{ Cardiovascular } & clonidine & $1(2,2)$ & Low & $\begin{array}{l}\text { Potential orthostatic hypotension and adverse effects on the central } \\
\text { nervous system. }\end{array}$ \\
\hline & methyldopa & $5(11,2)$ & High & Can cause bradycardia and exacerbate depression in elderly. \\
\hline & digoxin & $3(6,7)$ & Low & $\begin{array}{l}\text { Must not exceed } 0.125 \mathrm{mg} / \mathrm{d} \text {, except in treatment of atrial } \\
\text { arrhythmias; reduces the renal clearance and can lead to renal toxic } \\
\text { effects. }\end{array}$ \\
\hline & codergocrine & $2(4,4)$ & Low & Has not proved effective in the doses used. \\
\hline & amiodarone & $2(4,4)$ & High & $\begin{array}{l}\text { It is associated with problems in the QT interval and risk of causing } \\
\text { torsades de pointes; lack of efficacy in elderly. }\end{array}$ \\
\hline & doxazosin & $1(2,2)$ & Low & Potential hypotension, dry mouth and urinary problems. \\
\hline & hydroxyzine & $1(2,2)$ & High & Has potent anticholinergic activity. \\
\hline Antibiotic & nitrofurantoin & $3(6,7)$ & High & Potential renal problems; safer alternatives are available. \\
\hline Genito-urinary & oxybutynin & $2(4,4)$ & High & $\begin{array}{l}\text { Is not well tolerated by elderly for causing anticholinergic adverse } \\
\text { effects, sedation and weakness; furthermore, its effectiveness in } \\
\text { doses tolerated by the elderly is questionable. }\end{array}$ \\
\hline Digestive & cimetidine & $1(2,2)$ & Low & Adverse effects on the central nervous system, including confusion. \\
\hline
\end{tabular}

and are considered psychoactive drugs [benzodiazepines (28.9\%), antidepressants (15.6\%) and neuroleptics (8.9\%)]. Lucchetti et al. (2010) observed that $58.9 \%$ of the older people living in a long-term care facility were prescribed psychotropic drugs, mainly antidepressants and neuroleptics drugs. The prevalence of psychoactive substances reported in both studies may be explained by several factors, including: the pattern of utilization of these substances (chronic and continuous use by major adults and elderly people) (Laranjeira, Castro, 1999; Fraser, 1998), the high incidence of psychiatric diseases among institutionalized patients (Nakayama et al., 2004), and drug dependence or abuse.

The phenomenon of drug dependence in elderly people may be associated with misuse and abuse of psychotropic drugs, because according to Orlandi et al. (2005), many older patients start taking these substances when they are young or young adults. However, to prevent and minimize the negative outcomes associated with ir- rational and incorrect use, the treatment should not exceed four weeks, according to the World Health Organization (WHO, 1983).

Drug advertisements contribute to inappropriate prescriptions of psychoactive drugs as well. These kinds of publications have low level of scientific evidence and lack of reliability and accuracy of information disclosed to doctors (Mastroianni et al., 2008). The absence of adequate public policies in order to regulate information on drugs which is disseminated to physicians and the lack of monitoring of the content of advertisement (Mastroianni et al., 2003) are also factors that allow prescription errors. Thus, prescribers should have a critical attitude of regarding the drugs advertisements from pharmaceutical companies (Mastroianni et al., 2008), and should also properly assess the risk/benefit ratio of drug usage, based on officially recognized scientific literature. Greater attention should be given to patients considered at risk, such as the elderly people. 
TABLE II - Frequency of the drug interactions detected, involving PIM, according to the severity, those considered potentially hazardous and the negative clinical outcomes for the elderly, Araraquara, SP, Brazil $(n=13)$

\section{Dug-drug interaction}

\begin{tabular}{cccccc}
\hline Drug A & Drug B & N & Result & $\begin{array}{c}\text { Potentially } \\
\text { hazardous }\end{array}$ & Severity \\
\hline amitriptyline & diazepam & $1(4.5)$ & May cause psychomotor deficit & No & Moderate \\
amitriptyline & phenytoin & $1(4.5)$ & Can result in toxic effect of phenytoin & Yes & Moderate \\
amitriptyline & carbamazepine & $1(4.5)$ & Can decrease effectiveness of amitriptyline & Yes & Moderate \\
amitriptyline & haloperidol & $1(4.5)$ & Can raise the risk of cardiotoxicity & Yes & Major \\
diazepam & haloperidol & $4(18.2)$ & Can raise the sedative effect & No & $-*$ \\
diazepam & phenytoin & $3(13.7)$ & May change the serum concentration of & No & Moderate \\
& & & phenytoin & No & $-*$ \\
diazepam & hydrochlorothiazide & $3(13.7)$ & Can raise the hypotensive effect & No & $-*$ \\
diazepam & methyldopa & $2(9.2)$ & Can raise the hypotensive effect & Yes & Moderate \\
digoxin & furosemide & $1(4.5)$ & Can result in digitalis toxicity & Yes & Major \\
digoxin & hydrochlorothiazide & $1(4.5)$ & Can result in digitalis toxicity & Yes & Moderate \\
digoxin & nifedipine & $1(4.5)$ & Can result in digitalis toxicity & No & $-*$ \\
methyldopa & clonazepam & $1(4.5)$ & Can raise the hypotensive effect & No & $-*$ \\
methyldopa & hydrochlorothiazide & $2(9.2)$ & Can raise the hypotensive effect & &
\end{tabular}

*- Micromedex database does not detect the concomitant use of these drugs as drug interaction. Therefore, it was not possible to analyze the severity. However, in the WHO Model Formulary (2004) there are descriptions of these drug interactions.

Studies have shown that polypharmacy is a risk factor for PIM prescription (Varallo et al., 2011; Ruggiero et al., 2010; Locatelli et al., 2010; Azoulay et al., 2005). Our findings corroborate data of the literature, since older people who used five or more medications had higher number of prescribed PIM when compared with elderly individuals who are not polypharmacy users $(\mathrm{p}<0.0001)$. However, for geriatric patients aged $\geq 80$ years, there is no evidence that polypharmacy increases the odds of PIM prescription. According to Azoulay et al. (2005), possible reasons for the occurrence of this prescription error are related to the absence of safer equivalent therapeutics available for use in the elderly people, the inexperience of physicians in clinical practice and the need for adjustments in the curriculums of health courses.

Castelar et al. (2007) found that polypharmacy is also a risk factor for the occurrence of serious and potentially hazardous drug interactions (PHDI). In the present study, 22 drug interactions involving PIM were identified, of which $27.3 \%(6 / 22)$ are considered PHDI, according to WHO criteria (WHO, 2004). Considering that the elderly people are more predisposed to the occurrence of drug interactions due to polypharmacy, the prescriber has the responsibility to elaborate therapeutic schemes with fewer numbers of drugs and to consider the possibility of non-pharmacological treatments, in order to avoid coprescription with the potential to interact with each other. On the other hand, if the prescription of drug interaction is inevitable (when there are no other options available), it is necessary to adjust the dose or the time of administration of each drug, to minimize or prevent adverse clinical outcomes that might occur due to the drug interaction (WHO, 2004; Seymour, Routledge, 1998).

The proposed methodology of pharmaceutical intervention (PI) did not bring about changes in drug prescriptions for elderly people who had prescribed PIM and identified PHDI. Although the PI did not reach the expected impact, it is relevant to highlight that it may contribute to improve the quality of medical prescription for elderly people, once most of the physicians lack knowledge regarding explicitly validated criteria for safe drug use in the elderly, such as Beers criteria (Beers, 1991; Beers et al., 1997; Fick at al., 2003) and Screening Tool of Older Person's Prescriptions - STOPP - (Gallagher et al., 2008b; Gallagher et al., 2009). Since the list of medicines approved by sanitary surveillance may vary among countries, it is also important that each country develop a proper consensus in order to establish a list of PIM, as 
TABLE III - Pharmaceutical intervention: suggestion of therapeutic equivalents possibly safer for the elderly, and the justification of the choice. Araraquara, SP, Brazil $(n=14)$

\begin{tabular}{|c|c|c|}
\hline Drug & $\begin{array}{l}\text { Therapeutic } \\
\text { Equivalent }\end{array}$ & Justification \\
\hline Amiodarone & propranolol & $\begin{array}{l}\text { propranolol has reduced presystemic metabolism, has no active metabolites, and presents } \\
\text { cardioprotective effects (Hardman, Limbird, 2003). }\end{array}$ \\
\hline Amitriptylin & sertraline & $\begin{array}{l}\text { sertraline has fewer anticholinergic effects, sedation, hypotension and cardiac effects } \\
\text { (Hardman, Limbird, 2003). }\end{array}$ \\
\hline Clonidin & losartan & $\begin{array}{l}\text { It is suggested as a substitution for other antihypertensive drug, such as losartan, except } \\
\text { calcium channel blockers and reserpine (Laroche et al., 2007). }\end{array}$ \\
\hline Diazepam & $\begin{array}{l}\text { short acting } \\
\text { benzodiazepine }\end{array}$ & $\begin{array}{l}\text { Short acting benzodiazepines are recommended, such as lorazepam or oxazepam, } \\
\text { since they do not have active metabolites and are metabolized only in conjunction with } \\
\text { glucuronic acid (Hardman, Limbird., 2003). }\end{array}$ \\
\hline Doxazosin & losartan & $\begin{array}{l}\text { The use of doxazosin is indicated only if there is contraindication to other antihypertensive } \\
\text { drugs or if the patient has severe hypertension, starting with low doses and slow adjustment } \\
\text { to the lowest effective dose. Otherwise, substitute the drug to other class in accordance } \\
\text { with other possible comorbidities (Cavalcanti et al., 2006). }\end{array}$ \\
\hline Fluoxetine & sertraline & $\begin{array}{l}\text { sertraline has fewer anticholinergic effects, sedation, hypotension and cardiac effects } \\
\text { (Hardman, Limbird, 2003). }\end{array}$ \\
\hline Hydroxyzine & loratadine & It is preferable to the use of loratadine due to its reduced sedation (Laroche et al., 2007). \\
\hline Codergocrine & ginkgo biloba & $\begin{array}{l}\text { Ginkgo biloba is effective and causes no significant adverse effects (Kleijnen, Knipschild, } \\
\text { 1992). }\end{array}$ \\
\hline oxybutynin & tolterodine & $\begin{array}{l}\text { tolterodine causes few cognitive adverse effects and has greater selectivity for bladder } \\
\text { (Hardman, Limbird, 2003) }\end{array}$ \\
\hline Tioridazine & fluphenazine & $\begin{array}{l}\text { fluphenazine has weaker sedative, anticholinergic and hypotensive effects (Korolkovas, } \\
\text { França, 2009). }\end{array}$ \\
\hline
\end{tabular}

observed in the study conducted by Holt et al. (2010).

One of the reasons which may explain the poor results obtained is that the letter may not be the most effective method to lead to changes in the parameters evaluated, possibly due to the distance and impersonality among the professionals involved (physicians and pharmacists). Grimshaw et al. (2001) found that simple interventions, such as sending educational materials for physicians, are generally ineffective in promoting changes in the behavior of those professionals, when used as the only interventional method. However, the authors suggest that this practice is useful to raise awareness of the problem. They also noted that multifaceted interventions should be used based on the factors involved in the resistance health professionals have as regards changing their prescription behavior. This fact can be explained by the principle of andragogy, which asserts that adult apprenticeship is much more effective when it is related to factors of information acquisition (either through visual or listening sources), associated with practical applications of concepts and particular experiences. Therefore, educational intervention with other techniques, in addition to the expository meth- 
od, including all experts who assist the elderly residents in the studied institution, would be an important component to promote effective pharmacotherapeutic adjustments for patients who had PIM or DI prescribed.

Another issue that contributed to the non-adherence to the intervention may be the drugs selected in the longterm care, which are arising from Public Health Sector. In the institution studied, the selection of drugs is based on the national and municipal lists of essential medicines. Therefore, half of the safer alternatives proposed are not available (e.g. short-acting benzodiazepines, fluphenazine, Ginkgo biloba, sertraline and tolterodine), since they are not considered essential medicines, according to the National List of Essential Medicines (RENAME 2010) and the Municipal List of Essential Medicines (REMUME). Moreover, the residents of the institution did not have financial means that would allow the purchase of these safer therapeutic alternatives. Thus, the inclusion of the therapeutic equivalents proposed in the Brazilian public health drug lists (RENAME and REMUME) is recommended, especially fluphenazine and lorazepam (short-acting benzodiazepinic) which are contemplated in the $16^{\text {th }} \mathrm{WHO}$ Model List of Essential Medicines, in order to contribute to the indication of safer drugs for the elderly people.

Strategies that may be useful to prevent the use of PIM and the prescription of PHDI are the wide dissemination, among health professionals, of lists of medications considered inappropriate for the elderly and the drugs involved in DI. Grimshaw et al. (2001) conducted a systematic review of studies of educational interventions and found that the disclosure and use of educational reminders are effective strategies that can be employed to change the behavior of health professionals. In addition, the pharmaceutical care for elderly people should be an active practice in all levels of health care, in order to detect and solve real and/or potential drug related problems, and to prevent negative outcomes associated with medications, as well as to ensure drugs and patient safety.

\section{Study limitations}

The main limitation of the present study is the sample size, which makes it difficult to infer data for other long-term care institutions. Moreover, we did not have access to the physicians who were not linked to the institution studied. Therefore, the intervention was performed for a single prescribing professional, who was responsible for the pharmacotherapy management in the institution and who did not adhere to the suggestions proposed. Thus, if all prescribers involved in the treatment of the elderly had been identified and included in pharmaceutical intervention, maybe alterations in the prescriptions which con- tained PIM could have been observed. Furthermore, the prevalence of use of PIM may have been underestimated, due to Beers criteria, since this method does not cover all drugs available in Brazil and includes several drugs that have not been approved for use in our country.

\section{CONCLUSION}

PIM prescription is common for elderly residents in long-term care facilities. Therefore, the analysis of drug prescription is recommended, especially for older patients receiving polypharmacy and for those who use psychoactive drugs, in order to prevent drug dependence; deal with the cases in which there is abuse of drugs, or when judicious pharmacotherapeutic management for withdrawal and/or replacement of drugs is required. Therefore, it is possible to detect and prevent drug related problems and negative outcomes associated with medications, to propose changes in treatment regimens with the objective of preventing serious and hazardous drug interactions and to detect the need of inclusion of safer therapeutic equivalents for the elderly (such as short-acting benzodiazepines, fluphenazine, the Ginkgo biloba, sertraline and tolterodine) in the national and municipal lists of essential medicines.

\section{REFERENCES}

AKAZAWA, M.; IMAI, H.; IGARASHI, A.; TSUTANI, K. Potentially inappropriate use in elderly Japanese patients. Am. J. Geriatr. Pharmacother., v.8, p.146-160, 2010.

ALBERT, S.; COLOMBI, A.; HANLON, J. Potentially inappropriate medications and risk of hospitalization in retirees. Drugs Aging, v.27, p.407-415, 2010.

AZOULAY, L.; ZARGARZADEH, A.; SALAHSHOURI, Z.; ORAICHI, D.; BÉRARD, A. Inappropriate medication prescribing in community-dwelling elderly people living in Iran. Eur. J. Clin. Pharmacol., v.61, p.913-919, 2005.

BEERS, M.H.; OUSLANDER, J.G.; ROLLINGHER, J; REUBEN, D.B.; BECK, J.C. Explicit Criteria for determining inappropriate medication use in nursing home residents. Arch. Intern. Med., v.151, p.1825-32, 1991.

BONGUE, B.; NAUDIN, F.; LAROCHE, M.L.; GALTEAU, M.M.; GUY, C.; GUÉGUEN, R.; CONVERS, J. P.; COLVEZ, A.; MAAROUF, N. Trends of the potentially inappropriate medcation consumption over 10 years in older adults in East of France. Pharmacoepidemiology D. S., v.18, p.1125-1133, 2009. 
CARVALHO, J.A.M.; GARCIA, R.A. O envelhecimento da população brasileira: um enfoque demográfico. Cad. Saúde Pública, v.19, p.725-733, 2003.

CASTELINO, R.L.; BAJOREK, B.V.; CHEN, T.F. Targeting suboptimal prescribing in the elderly: a review of the impact of pharmacy services. Ann. Pharmacother., v.43, p.10961106, 2009.

CASTELLAR, J.; KARNIKOWSKI, M.G.O.; VIANNA, L.G.; NÓBREGA, O.T. Estudo da farmacoterapia prescrita a idosos em instituição brasileira de longa permanência. Acta Med. Port., v.20, p.97-105, 2007.

SOCIEDADE BRASILEIRA DE UROLOGIA. Hiperplasia prostática benigna. (Projeto Diretrizes), 2006. 19 p.

CORSONELlO, A.; PEDONE, C.; INCALZI, R.A. AgeRelated Pharmacokinetic and Pharmacodynamic Changes and Related Risk of Adverse Drug Reactions. Curr. Med. Chem., v.17, p.571-584, 2010.

FICK, D.M.; COOPER, J.W.; WADE, W.E.; WALLER, J.L.; MACLEAN, J.R.; BEERS, M.H. Updating the Beers Criteria for potentially inappropriate medication use in older adults: results of a US consensus panel of experts. Arch. Intern. Med., v.163, p.2716-2724, 2003.

FICK, D.M.; MION, L.C.; BEERS, M.H.; WALLER, J.L. Health Outcomes Associated With Potentially Inappropriate Medication Use in Older Adults. Res. Nurs. Health, v.31, p.42-51, 2008.

FRANÇA, F.F.A.C.; KOROLKOVAS, A. Dicionário Terapêutico Guanabara. 16.ed. Rio de Janeiro: Guanabara Koogan, 2010. 686 p.

FRASER, A.D. Use and abuse of the benzodiazepines. Ther. Drug Monit., v.20, p.481-489, 1998.

GALLAGHER, P.F.; BARRY, P.J.; RYAN, C.; HARTIGAN, I.; $\mathrm{O}^{\prime} \mathrm{MAHONY}$, D. Inappropriate prescribing in an acutely ill population of elderly patients as determined by Beer's criteria. Age Aging, v.37, p.96-101, 2008a.

GALLAGHER, P.; RYAN, C.; BYRNE, S.; KENNEDY, J.; O'MAHONY, D. STOPP (Screening Tool of Older Person's Prescriptions) and START (Screening Tool to Alert doctors to Right Treatment). Consensus validation. Int. J. Clin. Pharmacol. Ther. Toxicol., v.46, p.72-83, 2008 b.
GALLAGHER, P.; BAEYENS, J.P.; TOPINKOVA, E.; MADLOVA, P.; CHERUBINI, A.; GASPERINI B.; JENTO, A.C.; MONTERO, B.; LANG, P.O.; MICHEL, J.P.; O'MAHONY, D. Inter-rater reliability of STOPP (Screening Tool of Older Persons' Prescriptions) and START (Screening Tool to Alert doctors to Right Treatment) criteria amongst physicians in six European countries. Age Aging, v 38, p.603-606, 2009.

GORDILHO, A.; SÉRGIO, J.; SILVESTRE, J.; RAMOS, L. R.; FREIRE, M. P. A.;, ESPÍNDOLA, N.; MAIA, R.; VERAS, R.; KARSCH, U. Desafios a serem enfrentados no terceiro milênio pelo setor saúde na atenção integral do idoso. Available at: <http://www.unati.uerj.br/publicacoes/ textos_Unati/unatil.pdf>.Accessed on: 10 Feb. 2011.

GRIMSHAW, J.M.; SHIRRAN, L.; THOMAS, R.; MOWATT, G.R.; FRASER, C.; BERO, L.; GRILLI, R.; HARVEY, E.; OXMAN, A.; O'BRIEN, M.A. Changing Provider Behavior. An Overview of systematic reviews of interventions. Med. Care, v.39, suppl.2, p.II2-II45, 2001.

HARDMAN, J.G.; LIMBIRD, L.E. (Eds.). Goodman \& Gilman As bases farmacológicas da terapêutica. 10.ed. Rio de Janeiro: McGraw-Hill, 2003. 1821 p.

HOLT, S.; SCHMIEDL, S.; THÜRMANN, P.A. Potentially Inappropriate Medications in the Elderly: The PRISCUS List. Dtsch. Ärztebl. Int., v.107, p.543-551, 2010.

INSTITUTO BRASILEIRO DE GEOGRAFIA E ESTATÍSITCA. Indicadores Sociodemográficos e de Saúde. Sobre a condição de saúde dos idosos: indicadores selecionados. Estudos e Pesquisas Informação Demográfica e Socioeconômica n.25. Rio de Janeiro: Ministério do Planejamento, Orçamento e Gestão, 2009. 152p.

KLEIJNEN, J.; KNIPSCHILD, P. Ginkgo biloba for cerebral insufficiency. Br. J. Clin. Pharmac., v.34, p.352-358, 1992.

KLOTZ, U.; MÖRIKE, K.; SHI, S. The clinical implications of aging for rational drug therapy. Eur. J. Clin. Pharmacol., v.64, p.183-199, 2008.

LARANJEIRA, R.; CASTRO, L.A. Potencial de abuso de benzodiazepínicos. In: BERNIK, M.A. (Ed.). Benzodiazepínicos, quatro décadas de experiência. São Paulo: Edusp, 1999. p.187-198. 
LAROCHE, M.L.; CHARMES, J.P.; MERLE, L. Potentially inappropriate medication in the elderly: a French consensus panel list. Eur. J. Clin. Pharmacol., v.63, p.725-731, 2007.

LOCATELLI, J.; LIRA, A.R.; TORRAGA, L.K.L.A.; PAES, A.T. Inappropriate Medications Using the Beers Criteria in Brazilian Hospitalized Elderly Patients. Consult. Pharm., v.25, p.36-40, 2010.

LUCCHETTI, G.; GRANERO, A.L.; PIRES, S.L.; GORZONI, M.L.; TAMAIS, S. Factors associated with the use of psychoactive drugs in institutionalized elderly. Rev. Psiquiatr. Rio Gd. Sul, v.32, p.38-43, 2010.

MASTROIANNI, P.C.; GALDURÓZ, J.C.F.; CARLINI, E.A. Influence of the legislation on the advertisement of psychoactive medications in Brazil. Rev. Bras. Psiquiatr., v.25, p.146-55, 2003.

MASTROIANNI, P.C.; NOTO, A.R.; GALDURÓZ, J.C.F. Propagandas de medicamentos psicoativos: análise das informações científicas. Rev. Saúde Publ., v.42, p.529-535, 2008.

MORAIS, P.C.M. Avaliação do consumo de medicamentos em instituição asilar. Rio de Janeiro, 1998.99 p. [Dissertation of Master degree. Health Sciences Center. Federal University of Rio de Janeiro].

NAKAYAMA, L.Y.; ASSEF, K.M.; DELLA-TORRE, A.; VALENTE, M.; CARMO, F.S.; GORZONI, M.L. Estudo de 93 idosos institucionalizados em unidade de alta dependência. Gerontology, v.12, p.65, 2004.

O'MAHONY, D.; GALLAGHER, P. Inappropriate prescribing in the olderpopulation: need for new criteria. Age Aging, v.37, p.138-141, 2008.

ORLANDI, P.; NOTO, A.R. Uso indevido de benzodiazepínicos: um estudo com informantes-chave no município de São Paulo. Rev. Lat. Am. Enferm., v.13, p.896-902, 2005.
ROZENFELD, S. Prevalência, fatores associados e mau uso de medicamentos entre os idosos: uma revisão. Cad. Saúde Pública, v.19, p.712-724, 2003.

RUGGIERO, C.; DELL'AQUILA, G.; GASPERINI, B.; LATTANZIO, F.; VOLPATO, S.; CORSONELLO, A.; MARALDI, C.; BERNABEI, R.; CHERUBINI, A. Potentially inappropriate drug prescriptions and risk of hospitalization among older, Italian, nursing home residents: the ULISSE project. Drugs Aging, v.27, n.9, p.747-758, 2010.

SEYMOUR, R.M.; ROUTLEDGE, P.A. Important drug-drug interactions in the elderly. Drugs Aging, v.12, p.485-494, 1998.

SILVA, P. Farmacologia. 7ed. Rio de Janeiro: Guanabara Koogan, 2006.1398 p.

VARALLO, F.R.; CAPUCHO, H.C.; PLANETA, C.S.; MASTROIANNI, P.C. Safety Assessment of potentially inappropriate medications (pim) use in older people and the factors associated with hospital admission. J. Pharm. Pharm. Sci., v.14, p.283-290, 2011.

WORLD HEALTH ORGANIZATION (WHO). Use and abuse Benzodiazepines, 1983. Bull. WHO, v.4, p.551-562, 1983.

MEHTA, D.K.; RYAN, R.S.M.; HOGERZEIL, H.V. (Ed.) WHO model formulary 2004. Based on the 13th model list of essential medicines 2003. Geneva: World Health Organization, 2004. 548 p.

Received for publication on $19^{\text {th }}$ December 2011 Accepted for publication on $20^{\text {th }}$ June 2012 
